\title{
THE EVALUATION OF LEARNING MANAGEMENT SYSTEMS BY USING FUZZY AHP, FUZZY TOPSIS AND AN INTEGRATED METHOD: A CASE STUDY
}

\author{
Yasemin ALTUN TURKER \\ ORCID: 0000-0001-8857-2828 \\ Institute of Natural Sciences, Department of Industrial Engineering \\ Sakarya \& Karabuk University \\ Karabuk, Turkey \\ Dr. Kasim BAYNAL \\ ORCID: 0000-0003-1448-5937 \\ Faculty of Engineering, Kocaeli University \\ Kocaeli, Turkey \\ Turgay TURKER \\ ORCID: 0000-0002-3793-657X \\ Institute of Natural Sciences, Department of Industrial Engineering \\ Sakarya University \\ Sakarya, Turkey
}

Received: 07/06/2016 Accepted: 10/06/2017

\begin{abstract}
Distance Education has become an important educational model with the development of information and communication technologies in the world. It has also become increasingly used model in Turkey. In our country, the number of universities and educational organizations offering distance education programs increase day by day. Distance education is performed by some special software called Learning Management System (LMS). There are both commercial LMSs and several open-source LMSs that have cost advantages. It is difficult to select an appropriate LMS for many institutions to meet their standards. The decision making and selection process is crucial, because LMS functions are different from each other, and they all have various features. Because of this, in this study, it is targeted to help and facilitate the decision-making process of LMS for institutions. In this study, Fuzzy AHP (Analytic Hierarchy Process), Fuzzy TOPSIS (Technique for Order Preference by Similarity to Ideal Solution) and an integrated method were used for evaluating criteria and deciding alternatives. To help accomplish this aim, questionnaire forms was designed and used for data collection. These methods were compared with each other. Results were evaluated. According to results among different criteria, the most important criteria for selecting LMS alternatives was found Content Management and Development (96.3\%) and between the alternatives Moodle was found the best alternative with the degree of $36.3 \%$.
\end{abstract}

Keywords: Fuzzy AHP, fuzzy TOPSIS, learning management system, distance education.

\section{INTRODUCTION}

In today's information age, computer and information technologies improve rapidly day by day. Thanks to developing technologies, the human life has become easier. The changing education model can be showed as an example of easier life. Rapid technological developments and the widespread usage of the Internet, has 
caused changes in the understanding of education and distance education has become an important role in teaching and learning.

Distance education is a way of teaching and planned learning in which teaching activities occurs in a different place from special courses, teaching techniques and communication by using technology (Moore and Kearsley, 2005). It varies according to the face-to-face training in terms of courses management, teacher roles, instructional design, interaction strategies, the support systems given to learners, evaluation process and general administrative services (Olcott, 2003; Stella and Gnanam, 2004) and it can be performed some tools such as computer and multimedia technology. Thus, the concept of distance education or e-learning has emerged. Because e-learning activities are performed in web, the concept of distance education and elearning started to be used interchangeably. E-learning is a subset of distance education that was common since the middle of 1980s (Hassanzadeh et al., 2012). E-learning can be defined as; the distribution of required information for education and training with communication tools (Sun et al., 2008; Reis et al., 2012) or using internet and new multimedia technologies for improve quality of education by facilitating access to education resources with services like co-operation and sharing information (Itmazi et al., 2005; Reis et al., 2012). With spread internet usage, e-learning became vastly widespread and many universities put it in their program (Kanuka and Anderson, 2007). According to the Giga Information Group, nearly $75 \%$ of the 129 top US universities use e-learning systems (Wang and Wang, 2009) and 95\% of higher education institutions in the UK have established e-learning systems (Browne et al., 2006; Loon and Teasley, 2009). The number of universities offering distance education in Turkey is increasing as time goes on. The number of the universities offering distance education refers to nearly $80 \%$ of the total number of universities.

The distance education is performed by some special software called Learning Management Systems. LMS is an e-learning infrastructure and has many functions such as creating time-independent course materials, monitoring, sharing and discussing of these materials at anytime and anywhere, updating and reporting all of the systems information. There is commercial and open source software used in e-learning. Many universities prefer the open-source software for e-learning. By this way, the cost disadvantages of e-learning are largely eliminated (Aydin and Birogul, 2008). ATutor, Ada, Moodle, Claroline, Ilias, Docebo, Dokeos, COSE, Olat, Sakai, TinyLMS, Jones e-education, Kewl-Nextgen and Fle3 are example of open-source software. As it is seen, there are different LMS types so we can say that it is difficult to select an appropriate LMS for many universities to meet their standards. The decision making and selection process is crucial because LMS functions are different from each other, and they all have various features. Because of this, in this study, it is targeted to help and facilitate the decision-making process of LMS for universities. We can say that, the aim of this study is to evaluate the criteria of LMS selection and decide the LMS alternatives according to defined criteria. We think that, this study is helpful for both universities and educational organizations to decide which type of LMS is preferred.

In the study Fuzzy AHP (FAHP), Fuzzy TOPSIS and an integrated method is used for evaluating process. In the literature, AHP and TOPSIS methods were applied to different areas and a limited number of studies on selecting LMS evaluation with AHP existence and there has not been yet a study using TOPSIS method or AHP-TOPSIS integrated on LMS evaluation. With this study, we want to fill this gap in the literature.

The remainder of this paper is organized as follows. Section 2 presents literature review on LMS and integrated fuzzy AHP-TOPSIS papers. Section 3 talks about Fuzzy Multiple Criteria Decision Making (MCDM). Section 4 represents the case study. The paper is concluded and the future directions are highlighted in Section 5. 


\section{LITERATURE REVIEW}

\section{Literature Review on Learning Management System}

In the literature, there are different studies regarding to defining Learning Management System criteria, comparing and evaluating LMS alternatives. Some of these are as following. Kaya (2012) investigated the LMS usage at universities in Turkey and Northern Cyprus. Which university uses which LMS is shown and the most used LMS was defined as MOODLE in this study. Reis et al. (2012) mentioned open-source LMS for web based learning, defined different evaluation criteria and made a detailed comparison of some of the open-source LMS alternatives based on these criteria. Alshomrani (2012) compared 8 LMS alternatives in terms of approximately 25 technical specifications. Usability, Collaboration features, Support for learning methods, Standards-oriented content authoring / importing such as IMS and SCORM, Multi Lingual Support were seen as the key points of technical specification and it showed the alternatives that meets these specifications were Moodle, ATutor and ILLIAS respectively. Cavus (2010) evaluated open-source LMS and commercial LMS by using an artificial intelligence fuzzy logic algorithm. At the end of study WebCT 4.0 for commercial LMS and MOODLE for open-source LMS were seen as the best LMS.

Chao and Chen (2009) presented a method to evaluate the LMS factors. By using consistent fuzzy preference relations (CFPR) in AHP, e-learning material was defined as the main criteria and the other criteria was defined as Quality of web learning platform, Synchronous learning, Self-learning, Learning record respectively. Chen and Li (2009) used fuzzy analytic hierarchy process to evaluate alternatives of distance education system in China. At the end of the study, Furite (an LMS alternative) was observed as the best alternative. Shee and Wang (2008) carried out a survey of college students to evaluate web based e-learning and AHP was used for analyzing the result of survey and Learner interface has been observed as the most important criteria. Aydin and Birogul (2008) gave information about open-source LMS, compared existing LMS and observed MOODLE is the best alternative. Colace and De Santo (2008) evaluated e-learning platform with AHP under 3 different scenarios.

\section{Literature Review on Integrated AHP-TOPSIS Studies}

In the literature, Integrated AHP-TOPSIS Studies can be seen. AHP-TOPSIS were used together; Tsaur et al. (2002) to evaluate the quality of airport services, Majumdar et al. (2005) to determine the quality value of cotton fibre; Mahmoodzadeh et al. (2007) for project selection Shyjith et al. (2008) to evaluate optimum maintenance strategy in textile industry, Yu et al. (2011) to rank business to customer (B2C) e-commerce websites in e-alliance Bakhoum and Brown (2013) for sustainable ranking of structural materials and Goh et al. (2013) used shedding scheme for large pulp mill electrical system.

\section{Fuzzy MCDM}

Multi criteria decision making problems often involve uncertainty and these problems are inherently vagueness and fuzziness. Fuzzy set theory was introduced by Zadeh (1965) and he used these problems to provide a mathematical way to represent vagueness and fuzziness in humanistic systems. It implements classes and grouping of data with boundaries that are not sharply defined (i.e., fuzzy) and it is easier to understand (Chan and Kumar, 2007).

\section{Fuzzy AHP}

Analytic hierarchy process (AHP) is a multi-criteria decision making method introduced by Saaty in 1970s and uses a pair-wise comparison method to obtain relative weights of criteria and alternative scores. The AHP is one of the most widely used MCDM methods. In spite of AHP method popularity; this method is often criticized because of its inability to handle uncertain and imprecise decision-making problems (Cheng 1999, Chan et al. 2008, Lee 2009). To eliminate this uncertainty in the decision making problems Fuzzy AHP based on fuzzy set theory was originally introduced by van Laarhoven and Pedrycz (1983). Later, 
academics have developed and used various fuzzy AHP methods for solving different problems (Chang 1996; Cheng et al., 1999; Mikhailov 2002; Kahraman et al., 2004; Gu and Zhu, 2006).

Chang (1996) introduced a new approach for handling pair-wise comparison based on triangular fuzzy numbers followed by use of extent analysis method for synthetic extent value of the pair-wise comparison. Traditional fuzzy AHP methods deal with fuzzy values by using tiring arithmetic calculations. Furthermore, another disadvantage of these methods is that they need more defuzzification process for achieving a certain result. Because of using the intersection of triangular fuzzy numbers method for calculations, these disadvantages are not valid for Chang's approach (Demirel et al., 2009). Therefore, Chang's approach has been used in this study. Linguistic variables and triangular fuzzy numbers (TFN) used in Fuzzy AHP are shown in Table 1.

Table 1. Linguistic variables and triangular fuzzy numbers for the evaluation

\begin{tabular}{lcc}
\hline Linguistic term & TFN & Inverse TFN \\
\hline Equally important & $(1,1,1)$ & $(1,1,1)$ \\
Weakly important & $(1,3,5)$ & $(1 / 5,1 / 3,1 / 1)$ \\
Essentially important & $(3,5,7)$ & $(1 / 7,1 / 5,1 / 3)$ \\
Very strongly important & $(5,7,9)$ & $(1 / 9,1 / 7,1 / 5)$ \\
Absolutely important & $(7,9,9)$ & $(1 / 9,1 / 9,1 / 7)$ \\
\hline
\end{tabular}

\section{Fuzzy TOPSIS}

The TOPSIS (Technique for Order Preference by Similarity to Ideal Solution) which was developed by Hwang and Yoon (1981) is one of the most popular ideal point methods. The method uses the concepts of a positive ideal solution and a negative ideal solution to solve MCDM problems. The best alternative should have the shortest distance from the positive-ideal solution point and the longest distance from the negativeideal solution point (Razmi et al. 2009). Chen (2000) extended this method to fuzzy group decision making, using triangular fuzzy numbers and describing Euclidean distance between two fuzzy numbers. Fuzzy TOPSIS is applied in this study because of its basic concept and wide applications, such as those described by Shih (2008) and Chen and Hung (2010). Linguistic terms and triangular fuzzy numbers, used in Fuzzy TOPSIS are shown in Tables 2 and Table 3.

Table 2. Linguistic terms and fuzzy membership functions for criteria weights

\begin{tabular}{lc}
\hline Linguistic term & Fuzzy membership functions \\
\hline Very high (VH) & $(0.9,1,1)$ \\
High (H) & $(0.7,0.9,1)$ \\
Medium High (MH) & $(0.5,0.7,0.9)$ \\
Medium (M) & $(0.3,0.5,0.7)$ \\
Medium low (ML) & $(0.1,0.3,0.5)$ \\
Low (L) & $(0,0.1,0.3)$ \\
Very low (VL) & $(0,0,0.1)$ \\
\hline
\end{tabular}


Table 3. Linguistic terms and fuzzy membership functions for alternatives

\begin{tabular}{lc}
\hline Linguistic term & Fuzzy membership functions \\
\hline Very good (VG) & $(9,10,10)$ \\
Good (G) & $(7,9,10)$ \\
Medium good (MG) & $(5,7,9)$ \\
Fair (F) & $(3,5,7)$ \\
Medium poor (MP) & $(1,3,5)$ \\
Poor (P) & $(0,1,3)$ \\
Very poor (VP) & $(0,0,1)$ \\
\hline
\end{tabular}

\section{CASE STUDY}

In the literature, AHP and TOPSIS methods were applied to different areas and a limited number of studies on selecting LMS evaluation with AHP existence and there has not been yet a study using TOPSIS method or AHP-TOPSIS integrated on LMS evaluation. In this study, these two methods are used both separately and integratedly. The steps are as following;

Step 1: Establishing a committee of experts who are working at distance education department of different universities and determining the alternatives and sets of criteria and sub-criteria for evaluation. Criteria shown in Table 4 are defined according to users and expert opinions and other studies in literature (Shee and Wang, 2008; Aydin and Birogul, 2008; Ozan, 2008; Chao and Chen, 2009; Aydin and Tirkes, 2010; Reis et al., 2012). Alternatives are shown in Table 5. Popularity degree and common usage characteristic are taken into account during defining alternatives. Questionnaire forms used in this study are presented in Table 1-4 in the Appendix. Experts identified their opinions through linguistic scale in Table 1-3.

Table 4. Main and Sub-Criteria for LMS evaluation

\begin{tabular}{ll}
\hline Main Criteria & Sub-Criteria \\
\hline $\mathrm{C}_{1}$ : Ease of Use & $\mathrm{C}_{11}$ : Friendly Interface \\
& $\mathrm{C}_{12}$ : Flexible Systems \\
$\mathrm{C}_{2}$ : Communication, Interaction and & $\mathrm{C}_{21}$ : Discussion / Forum \\
Cooperation & $\mathrm{C}_{22}$ : Whiteboard \\
& $\mathrm{C}_{23}$ : Video Conferencing Support \\
& $\mathrm{C}_{24}$ : Social Networking \\
& $\mathrm{C}_{31}$ : Compliance with Teaching Standards \\
$\mathrm{C}_{3}:$ Content Management and & $\mathrm{C}_{32}$ : Content Sharing Tools \\
Development & $\mathrm{C}_{33}$ : Course Templates \\
& $\mathrm{C}_{41}$ : Online Help
\end{tabular}




\begin{tabular}{|c|c|}
\hline & $\mathrm{C}_{42:}$ Educational Support \\
\hline \multirow[t]{3}{*}{$\mathrm{C}_{5}$ : Productivity Tools } & $\mathrm{C}_{51}$ : Calendar \\
\hline & $\mathrm{C}_{52}$ : Searching Engine \\
\hline & $\mathrm{C}_{53}:$ Help Tool \\
\hline \multirow[t]{3}{*}{$\mathrm{C}_{6}:$ Measuring Tools } & $\mathrm{C}_{61}:$ Test / Exam tools \\
\hline & $\mathrm{C}_{62}$ : Question Bank Management \\
\hline & $\mathrm{C}_{63}:$ Automated Test Management \\
\hline \multirow[t]{2}{*}{$\mathrm{C}_{7}$ : Evaluation Tools } & $\mathrm{C}_{71}$ : Student Tracking \\
\hline & $\mathrm{C}_{72}$ : Courses / Training management \\
\hline \multirow[t]{2}{*}{$\mathrm{C}_{8}$ : Security } & $\mathrm{C}_{81}$ : Authentication \\
\hline & $\begin{array}{l}\mathrm{C}_{82} \text { : The Frequency of Publication of Security } \\
\text { Patch }\end{array}$ \\
\hline
\end{tabular}

Table 5. LMS Alternatives

\begin{tabular}{cl}
\hline Code & Alternative \\
\hline A1 & ATutor \\
A2 & Claroline \\
A3 & Sakai \\
A4 & Moodle \\
A5 & OLAT \\
A6 & Dokeos \\
\hline
\end{tabular}

Step 2: Constructing hierarchical structure. It is shown in Figure 1.

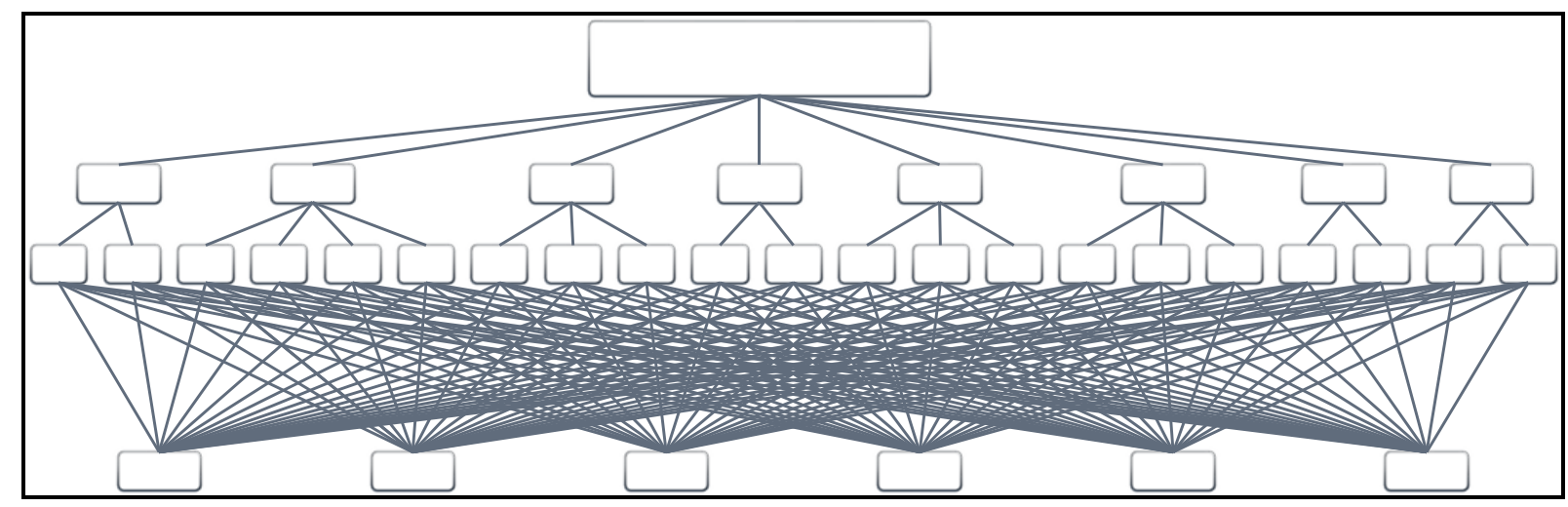

Figure 1. Hierarchical structure for LMS evaluation

Step 3: Application of Fuzzy AHP. The calculations of fuzzy AHP are made in Microsoft Excel program. Only basic calculations are shown in this article. Linguistic variables and triangular fuzzy numbers for the evaluation were shown in Table 1. 
Step 4: Application of Fuzzy TOPSIS. Linguistic terms and triangular fuzzy numbers used in Fuzzy TOPSIS have shown in Table 2 and Table 3.

Step 5: Application of Integrated Method. The criteria weights obtained by Fuzzy AHP are used during alternative ranking by Fuzzy TOPSIS.

Step 6: Comparing methods.

\section{Application of Fuzzy AHP}

As mentioned before, Chang's gradual Fuzzy AHP method is explained in study of Kahraman et al. (2004) and is used for this study.

Step 1: Constructing fuzzy pair wise comparison matrix. According to five expert's judgments for criteria, fuzzy pair wise comparison matrix is established. The comparison values, obtained by pair-wise comparison matrices are converted into a single value with geometric mean. These values are shown in Table 6.

Table 6. Fuzzy pair wise comparison matrix for main criteria

\begin{tabular}{|c|c|c|c|c|c|c|c|c|c|c|c|c|}
\hline & \multicolumn{3}{|c|}{$\mathrm{C}_{1}$} & \multicolumn{3}{|c|}{$\mathrm{C}_{2}$} & \multicolumn{3}{|c|}{$\mathrm{C}_{3}$} & \multicolumn{3}{|c|}{$\mathrm{C}_{4}$} \\
\hline & $\mathrm{L}$ & $M$ & $\mathrm{U}$ & $\mathrm{L}$ & M & U & $\mathrm{L}$ & M & U & $\mathrm{L}$ & M & U \\
\hline $\mathrm{C}_{1}$ & 1.000 & 1.000 & 1.000 & 0.491 & 0.714 & 1.185 & 0.148 & 0.204 & 0.394 & 0.204 & 0.301 & 0.509 \\
\hline $\mathrm{C}_{2}$ & 0.844 & 1.401 & 2.036 & 1.000 & 1.000 & 1.000 & 0.158 & 0.238 & 0.525 & 1.380 & 2.853 & 4.076 \\
\hline $\mathrm{C}_{3}$ & 2.537 & 4.904 & 6.766 & 1.904 & 4.210 & 6.325 & 1.000 & 1.000 & 1.000 & 4.146 & 6.534 & 8.002 \\
\hline $\mathrm{C}_{4}$ & 1.966 & 3.323 & 4.904 & 0.245 & 0.351 & 0.725 & 0.117 & 0.125 & 0.169 & 1.000 & 1.000 & 1.000 \\
\hline $\mathrm{C}_{5}$ & 1.070 & 1.552 & 2.141 & 0.200 & 0.333 & 1.000 & 0.138 & 0.184 & 0.316 & 1.403 & 1.933 & 2.709 \\
\hline $\mathrm{C}_{6}$ & 0.644 & 1.632 & 2.627 & 0.356 & 0.467 & 0.803 & 0.415 & 0.509 & 0.678 & 2.809 & 4.004 & 5.800 \\
\hline $\mathrm{C}_{7}$ & 2.627 & 4.988 & 7.114 & 0.258 & 0.375 & 0.803 & 0.415 & 0.536 & 0.725 & 1.807 & 2.809 & 4.004 \\
\hline \multirow[t]{2}{*}{$\mathrm{C}_{8}$} & 0.129 & 0.166 & 0.254 & 0.158 & 0.226 & 0.491 & 0.158 & 0.226 & 0.491 & 1.838 & 2.627 & 3.380 \\
\hline & & $\mathrm{C}_{5}$ & & & $\mathrm{C}_{6}$ & & & $\mathrm{C}_{7}$ & & & $\mathrm{C}_{8}$ & \\
\hline $\mathrm{C}_{1}$ & 0.467 & 0.644 & 0.935 & 0.178 & 0.268 & 0.678 & 0.141 & 0.200 & 0.381 & 3.936 & 6.015 & 7.740 \\
\hline $\mathrm{C}_{2}$ & 1.380 & 3.554 & 5.624 & 1.246 & 2.141 & 2.809 & 1.246 & 2.667 & 3.876 & 1.476 & 3.737 & 5.624 \\
\hline $\mathrm{C}_{3}$ & 3.160 & 5.431 & 7.237 & 1.476 & 1.963 & 2.408 & 1.380 & 1.867 & 2.408 & 2.809 & 5.245 & 7.114 \\
\hline $\mathrm{C}_{4}$ & 0.369 & 0.517 & 0.713 & 0.172 & 0.250 & 0.356 & 0.250 & 0.356 & 0.553 & 0.296 & 0.381 & 0.544 \\
\hline $\mathrm{C}_{5}$ & 1.000 & 1.000 & 1.000 & 0.725 & 1.125 & 1.719 & 0.296 & 0.422 & 0.725 & 0.422 & 0.602 & 1.070 \\
\hline $\mathrm{C}_{6}$ & 0.582 & 0.889 & 1.380 & 1.000 & 1.000 & 1.000 & 1.810 & 2.290 & 2.709 & 1.719 & 3.936 & 6.015 \\
\hline $\mathrm{C}_{7}$ & 1.719 & 2.627 & 3.615 & 0.369 & 0.437 & 0.552 & 1.000 & 1.000 & 1.000 & 3.680 & 5.720 & 7.740 \\
\hline $\mathrm{C}_{8}$ & 0.935 & 2.068 & 3.272 & 0.166 & 0.254 & 0.582 & 0.250 & 0.356 & 0.553 & 1.000 & 1.000 & 1.000 \\
\hline
\end{tabular}

L: Low, M: Medium, U: Upper.

Step 2: Checking the consistency of the comparison matrix. The fuzzy numbers should be firstly converted into matching crisp values for the following equation; 


$$
\frac{l+4 m+u}{6}
$$

The consistency process is made according to study of Zheng et al. (2012) and it is seen that the comparison matrix is consistent.

Step 3: The value of fuzzy synthetic extent is defined as; $\mathrm{SC} 1=(0.042,0.084,0.0185), \mathrm{SC} 2=(0.056,0.158$, $0.369), \operatorname{SC} 3=(0.118,0.279,0.569), \operatorname{SC} 4=(0.028,0.056,0.129), \operatorname{SC} 5=(0.034,0.064,0.0154)$, SC6 $=(0.060,0.132,0.304), S C 7=(0.076,0.166,0.369), S C 8=(0.030,0.062,0.145)$.

After applying other steps the weight vector for main criteria is obtained as;

$$
W=(0.074,0.194,0.287,0.014,0.041,0.0161,0.198,0.031)^{T}
$$

The same calculations are made for sub criteria and the weight vector for sub criteria is as following;

$$
W=\left(\begin{array}{l}
0.425,0.575,0.417,0.057,0.352,0.174,0.324,0.253,0.423,0.559, \\
0.441,0.220,0.401,0.379,0.220,0.222,0.469,0.441,0.559
\end{array}\right)^{T}
$$

Then, pair-wise comparisons of alternatives according to sub-criteria are made. The alternative values according to sub-criteria are shown in Table 7. By multiplying the values in Table 6 and sub criteria weight vector, Table 8 is obtained. By multiplying the values in Table 7 and main criteria weight vector, Table 9 is obtained.

Table 7. Alternative weights based on sub-criteria

\begin{tabular}{lccccccc}
\hline & $\mathrm{C}_{11}$ & $\mathrm{C}_{12}$ & $\mathrm{C}_{21}$ & $\mathrm{C}_{22}$ & $\mathrm{C}_{23}$ & $\mathrm{C}_{24}$ & $\mathrm{C}_{31}$ \\
\hline $\mathrm{A} 1$ & 0.225 & 0.216 & 0.293 & 0.268 & 0.241 & 0.217 & 0.212 \\
$\mathrm{~A} 2$ & 0.235 & 0.223 & 0.227 & 0.208 & 0.226 & 0.257 & 0.276 \\
$\mathrm{~A} 3$ & 0.033 & 0.000 & 0.000 & 0.000 & 0.000 & 0.000 & 0.000 \\
$\mathrm{~A} 4$ & 0.467 & 0.445 & 0.429 & 0.300 & 0.418 & 0.266 & 0.325 \\
$\mathrm{~A} 5$ & 0.000 & 0.000 & 0.000 & 0.000 & 0.000 & 0.099 & 0.000 \\
$\mathrm{~A} 6$ & 0.040 & 0.116 & 0.052 & 0.224 & 0.116 & 0.166 & 0.159 \\
\hline & $\mathrm{C}_{32}$ & $\mathrm{C}_{33}$ & $\mathrm{C}_{41}$ & $\mathrm{C}_{42}$ & $\mathrm{C}_{51}$ & $\mathrm{C}_{52}$ & $\mathrm{C}_{53}$ \\
\hline $\mathrm{A} 1$ & 0.239 & 0.235 & 0.225 & 0.256 & 0.256 & 0.288 & 0.202 \\
$\mathrm{~A} 2$ & 0.276 & 0.242 & 0.243 & 0.266 & 0.201 & 0.227 & 0.233 \\
$\mathrm{~A} 3$ & 0.000 & 0.000 & 0.000 & 0.069 & 0.000 & 0.000 & 0.000 \\
$\mathrm{~A} 4$ & 0.325 & 0.329 & 0.352 & 0.364 & 0.325 & 0.338 & 0.352 \\
$\mathrm{~A} 5$ & 0.000 & 0.013 & 0.087 & 0.000 & 0.048 & 0.000 & 0.018 \\
$\mathrm{~A} 6$ & 0.159 & 0.181 & 0.093 & 0.045 & 0.170 & 0.146 & 0.195 \\
\hline
\end{tabular}




\begin{tabular}{lccccccc}
\hline & $\mathrm{C}_{61}$ & $\mathrm{C}_{62}$ & $\mathrm{C}_{63}$ & $\mathrm{C}_{71}$ & $\mathrm{C}_{72}$ & $\mathrm{C}_{81}$ & $\mathrm{C}_{82}$ \\
\hline $\mathrm{A} 1$ & 0.242 & 0.248 & 0.221 & 0.221 & 0.213 & 0.223 & 0.202 \\
$\mathrm{~A} 2$ & 0.217 & 0.220 & 0.229 & 0.229 & 0.228 & 0.189 & 0.241 \\
$\mathrm{~A} 3$ & 0.000 & 0.000 & 0.000 & 0.000 & 0.000 & 0.050 & 0.035 \\
$\mathrm{~A} 4$ & 0.337 & 0.387 & 0.357 & 0.357 & 0.345 & 0.392 & 0.391 \\
$\mathrm{~A} 5$ & 0.018 & 0.000 & 0.000 & 0.000 & 0.021 & 0.000 & 0.000 \\
$\mathrm{A6}$ & 0.187 & 0.144 & 0.192 & 0.192 & 0.193 & 0.145 & 0.131 \\
\hline
\end{tabular}

Table 8. Alternative weights based on main criteria

\begin{tabular}{ccccccccc}
\hline & $\mathrm{C}_{1}$ & $\mathrm{C}_{2}$ & $\mathrm{C}_{3}$ & $\mathrm{C}_{4}$ & $\mathrm{C}_{5}$ & $\mathrm{C}_{6}$ & $\mathrm{C}_{7}$ & $\mathrm{C}_{8}$ \\
\hline $\mathrm{A} 1$ & 0.220 & 0.260 & 0.229 & 0.239 & 0.248 & 0.234 & 0.217 & 0.211 \\
$\mathrm{~A} 2$ & 0.228 & 0.231 & 0.262 & 0.253 & 0.223 & 0.223 & 0.228 & 0.219 \\
$\mathrm{~A} 3$ & 0.014 & 0.000 & 0.000 & 0.030 & 0.000 & 0.000 & 0.000 & 0.042 \\
$\mathrm{~A} 4$ & 0.455 & 0.389 & 0.327 & 0.357 & 0.341 & 0.358 & 0.351 & 0.391 \\
$\mathrm{~A} 5$ & 0.000 & 0.017 & 0.005 & 0.049 & 0.017 & 0.005 & 0.012 & 0.000 \\
A6 & 0.084 & 0.104 & 0.168 & 0.072 & 0.170 & 0.180 & 0.193 & 0.137 \\
\hline
\end{tabular}

Table 9. Importance weights of alternatives

\begin{tabular}{ccc}
\hline Code & Alternative & Weight \\
\hline A1 & Atutor & 0.233 \\
A2 & Claroline & 0.237 \\
A3 & Sakai & 0.004 \\
A4 & Moodle & 0.363 \\
A5 & Olat & 0.009 \\
A6 & Dokeos & 0.154 \\
\hline
\end{tabular}

Thus, based on Table 9, we infer that the alternative A4 is the optimal. The ranking order of the alternatives is given as $\mathrm{A} 4>\mathrm{A} 2>\mathrm{A} 1>\mathrm{A} 6>\mathrm{A} 5>\mathrm{A} 3$.

\section{Application of Fuzzy TOPSIS}

Step 1: Determining importance weights; the importance weights of each criteria are given by the five decision-makers as linguistic variables. The fuzzy weights of criteria are shown in Tables 10 and Table 11. 


\begin{tabular}{lccc}
\hline & $\mathrm{L}$ & $\mathrm{M}$ & $\mathrm{U}$ \\
\hline $\mathrm{C}_{1}$ & 0.260 & 0.460 & 0.660 \\
$\mathrm{C}_{2}$ & 0.740 & 0.920 & 1.000 \\
$\mathrm{C}_{3}$ & 0.860 & 0.980 & 1.000 \\
$\mathrm{C}_{4}$ & 0.140 & 0.340 & 0.540 \\
$\mathrm{C}_{5}$ & 0.500 & 0.700 & 0.900 \\
$\mathrm{C}_{6}$ & 0.700 & 0.900 & 1.000 \\
$\mathrm{C}_{7}$ & 0.740 & 0.920 & 1.000 \\
$\mathrm{C}_{8}$ & 0.060 & 0.220 & 0.420 \\
\hline
\end{tabular}

Table 11. Sub-criteria fuzzy importance weights

\begin{tabular}{cccc|cccc}
\hline & $\mathrm{L}$ & $\mathrm{M}$ & $\mathrm{U}$ & & $\mathrm{L}$ & $\mathrm{M}$ & $\mathrm{U}$ \\
\hline $\mathrm{C}_{11}$ & 0.260 & 0.460 & 0.660 & $\mathrm{C}_{51}$ & 0.460 & 0.660 & 0.860 \\
$\mathrm{C}_{12}$ & 0.420 & 0.620 & 0.820 & $\mathrm{C}_{52}$ & 0.620 & 0.820 & 0.960 \\
$\mathrm{C}_{21}$ & 0.780 & 0.940 & 1.000 & $\mathrm{C}_{53}$ & 0.660 & 0.860 & 0.980 \\
$\mathrm{C}_{22}$ & 0.620 & 0.820 & 0.960 & $\mathrm{C}_{61}$ & 0.700 & 0.900 & 1.000 \\
$\mathrm{C}_{23}$ & 0.740 & 0.920 & 1.000 & $\mathrm{C}_{62}$ & 0.700 & 0.900 & 1.000 \\
$\mathrm{C}_{24}$ & 0.700 & 0.900 & 1.000 & $\mathrm{C}_{63}$ & 0.780 & 0.940 & 1.000 \\
$\mathrm{C}_{31}$ & 0.740 & 0.920 & 1.000 & $\mathrm{C}_{71}$ & 0.780 & 0.940 & 1.000 \\
$\mathrm{C}_{32}$ & 0.660 & 0.860 & 0.980 & $\mathrm{C}_{72}$ & 0.740 & 0.920 & 1.000 \\
$\mathrm{C}_{33}$ & 0.860 & 0.980 & 1.000 & $\mathrm{C}_{81}$ & 0.780 & 0.940 & 1.000 \\
$\mathrm{C}_{41}$ & 0.180 & 0.380 & 0.580 & $\mathrm{C}_{82}$ & 0.260 & 0.460 & 0.660 \\
$\mathrm{C}_{42}$ & 0.220 & 0.420 & 0.620 & & & & \\
\hline
\end{tabular}

Step 2: Determining performance ratings; the performance ratings for the 6 alternatives are provided based on 21 sub-criteria by the five decision makers.

Step 3: Constructing normalized fuzzy decision matrix. The normalized fuzzy decision matrix is presented in Table 5 in the Appendix.

Step 4: Constructing weighted normalized fuzzy decision matrix. By multiplying Table 10 and Table 5 in the Appendix, the weighted normalized fuzzy decision matrix is obtained and given in Table 6 in the Appendix.

Step 5: Determining the ideal ( $\left.\mathrm{I}_{+}\right)$and anti-ideal (I-) solution for each alternative. Table 12 presents the distance of each alternative from (I+) and (I-). 
Table 12. Distance of each concept from ideal and anti-ideal solutions and closeness index

\begin{tabular}{crrc}
\hline $\begin{array}{c}\text { Alternative } \\
\text { Code }\end{array}$ & $\mathrm{d}_{\mathrm{i}}^{-}$ & $\mathrm{d}_{\mathrm{i}}^{+}$ & Closeness Index \\
\hline A1 & 13.960 & 8.893 & 0.611 \\
A2 & 13.650 & 9.219 & 0.597 \\
A3 & 2.176 & 19.276 & 0.101 \\
A4 & 15.245 & 7.371 & 0.674 \\
A5 & 3.674 & 18.061 & 0.169 \\
A6 & 6.804 & 15.405 & 0.306 \\
\hline
\end{tabular}

Step 6: Calculating closeness coefficient. Table 12 presents the closeness index of each alternative.

Thus, based on the values of the closeness index, we infer that the alternative $A 4$ is the optimal one. The ranking order of the alternatives is given as $\mathrm{A} 4>\mathrm{A} 1>\mathrm{A} 2>\mathrm{A} 6>\mathrm{A} 5>\mathrm{A} 3$.

\section{Integrated Fuzzy AHP-TOPSIS Application}

Stages of the integrated approach are shown in Figure 2. The criteria value, obtained by Fuzzy AHP is used when ranking alternatives by Fuzzy TOPSIS.

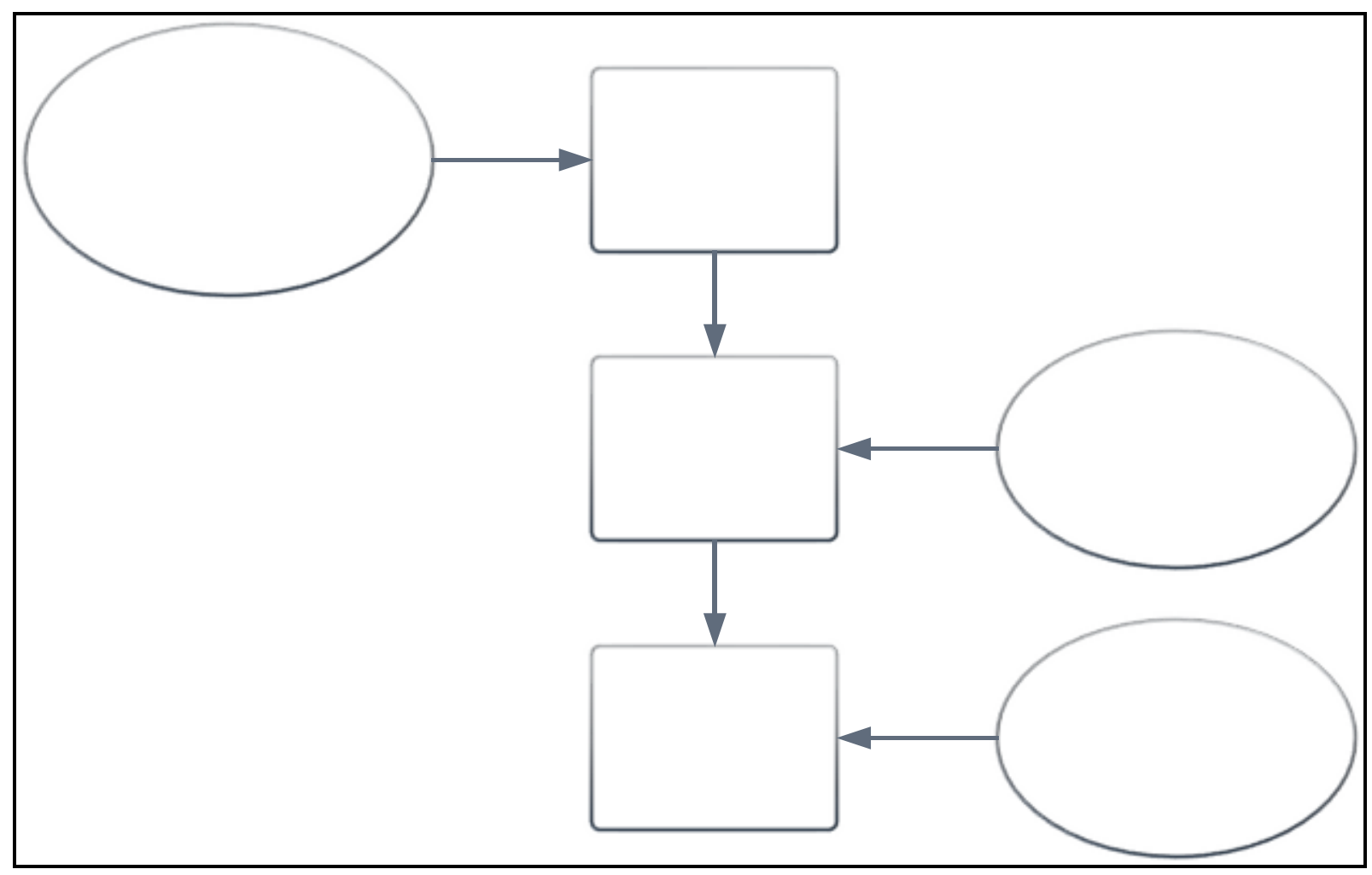

Figure 2. Stages of integrated method 
Step 1: Determining criteria importance weights. The criteria value, obtained by Fuzzy AHP is used.

Step 2: Determining performance ratings as shown in Fuzzy TOPSIS application.

Step 3: Constructing normalized fuzzy decision matrix. The normalized fuzzy decision matrix, obtained in Fuzzy TOPSIS is used.

Step 4: Constructing weighted normalized fuzzy decision matrix. By multiplying sub-criteria values are obtained by Fuzzy AHP and normalized fuzzy decision matrix, weighted normalized fuzzy decision matrix is obtained and given in Table 7 in the Appendix.

Step 5: Determining the ideal (I+) and anti-ideal (I-) solution for each alternative. Table 13 presents the distance of each alternative from (I+) and (I-).

Table 13. Distance of each concept from ideal and anti-ideal solutions and closeness Index

\begin{tabular}{cccc}
\hline Alternative Code & $\mathrm{d}_{\mathrm{i}}^{-}$ & $\mathrm{d}_{\mathrm{i}}^{+}$ & Closeness Index \\
\hline A1 & 6.692 & 14.433 & 0.317 \\
$\mathrm{~A} 2$ & 6.545 & 14.594 & 0.310 \\
$\mathrm{~A} 3$ & 0.918 & 20.235 & 0.043 \\
A4 & 7.477 & 13.564 & 0.355 \\
A5 & 1.663 & 19.567 & 0.078 \\
A6 & 2.819 & 18.461 & 0.132 \\
\hline
\end{tabular}

Step 6: Calculating closeness coefficient. Table 13 presents the closeness index of each alternative.

Thus, based on the values of the closeness index, we infer that the alternative A4 is the optimal one. The ranking order of the alternatives is given as $\mathrm{A} 4>\mathrm{A} 1>\mathrm{A} 2>\mathrm{A} 6>\mathrm{A} 5>\mathrm{A} 3$.

\section{Comparing Methods}

Tables 14 and Table 15 show criteria of values, obtained from Fuzzy AHP and Fuzzy TOPSIS respectively. The fuzzy numbers, obtained from Fuzzy TOPSIS are defuzzificated. Thus, an easier evaluation process is provided.

Table 14. Criteria weights for Fuzzy AHP

\begin{tabular}{cllc}
\hline Main Criteria & Weight & \multicolumn{1}{c}{ Sub-criteria } & Weight \\
\hline Ease of Use & 0.074 & $\mathrm{C}_{11}$ : Friendly Interface & 0.425 \\
& & $\mathrm{C}_{12}$ : Flexible Systems & 0.575 \\
\hline & & $\mathrm{C}_{21}:$ Discussion / Forum & 0.417 \\
$\begin{array}{c}\text { Communication, } \\
\text { Interaction and } \\
\text { Cooperation }\end{array}$ & 0.194 & $\mathrm{C}_{22}:$ Whiteboard & 0.057 \\
& & $\mathrm{C}_{23}:$ Video Conferencing support & 0.352 \\
& & $\mathrm{C}_{24}$ : Social networking & 0.174 \\
\hline
\end{tabular}




\begin{tabular}{|c|c|c|c|}
\hline \multirow{3}{*}{$\begin{array}{l}\text { Content Management } \\
\text { and Development }\end{array}$} & \multirow{3}{*}{0.287} & $\mathrm{C}_{31}$ : Compliance with Teaching Standards & 0.324 \\
\hline & & $\mathrm{C}_{32}$ : Content sharing tools & 0.253 \\
\hline & & $\mathrm{C}_{33}:$ Course templates & 0.423 \\
\hline \multirow[t]{2}{*}{ Support } & \multirow{2}{*}{0.014} & $\mathrm{C}_{41}:$ Online help & 0.559 \\
\hline & & $\mathrm{C}_{42:}$ Educational support & 0.441 \\
\hline \multirow{3}{*}{ Productivity Tools } & \multirow{3}{*}{0.041} & $\mathrm{C}_{51}$ : Calendar & 0.220 \\
\hline & & $\mathrm{C}_{52}$ : Searching Engine & 0.401 \\
\hline & & $\mathrm{C}_{53}:$ Help tool & 0.379 \\
\hline \multirow{3}{*}{ Measuring Tools } & \multirow{3}{*}{0.161} & $\mathrm{C}_{61}:$ Test / exam tools & 0.309 \\
\hline & & $\mathrm{C}_{62}:$ Question bank management & 0.222 \\
\hline & & $\mathrm{C}_{63}$ : Automated test management & 0.469 \\
\hline \multirow{2}{*}{ Evaluation Tools } & \multirow{2}{*}{0.198} & $\mathrm{C}_{71}$ : Student Tracking & 0.441 \\
\hline & & $\mathrm{C}_{72}$ : Courses / training management & 0.559 \\
\hline \multirow[t]{2}{*}{ Security } & \multirow{2}{*}{0.031} & $\mathrm{C}_{81}$ : Authentication & 0.441 \\
\hline & & $\mathrm{C}_{82}$ : The frequency of publication of Security Patch & 0.559 \\
\hline
\end{tabular}

Table 15. Criteria weights for Fuzzy TOPSIS

\begin{tabular}{|c|c|c|c|}
\hline Main Criteria & Weight & Sub-criteria & Weight \\
\hline \multirow{2}{*}{ Ease of Use } & \multirow{2}{*}{0.460} & $\mathrm{C}_{11}$ : Friendly Interface & 0.460 \\
\hline & & $\mathrm{C}_{12}:$ Flexible Systems & 0.620 \\
\hline \multirow{4}{*}{$\begin{array}{l}\text { Communication, } \\
\text { Interaction and } \\
\text { Cooperation }\end{array}$} & \multirow{4}{*}{0.903} & $\mathrm{C}_{21}$ : Discussion / Forum & 0.923 \\
\hline & & $\mathrm{C}_{22}$ : Whiteboard & 0.810 \\
\hline & & $\mathrm{C}_{23}$ : Video Conferencing support & 0.903 \\
\hline & & $\mathrm{C}_{24}$ : Social networking & 0.883 \\
\hline \multirow{3}{*}{$\begin{array}{l}\text { Content Management } \\
\text { and Development }\end{array}$} & \multirow{3}{*}{0.963} & $\mathrm{C}_{31}$ : Compliance with Teaching Standards & 0.903 \\
\hline & & $\mathrm{C}_{32}$ : Content sharing tools & 0.847 \\
\hline & & $\mathrm{C}_{33}$ : Course templates & 0.963 \\
\hline \multirow[t]{2}{*}{ Support } & \multirow{2}{*}{0.340} & $\mathrm{C}_{41}:$ Online help & 0.380 \\
\hline & & $\mathrm{C}_{42:}$ Educational support & 0.420 \\
\hline \multirow{2}{*}{ Productivity Tools } & \multirow{2}{*}{0.700} & $\mathrm{C}_{51}$ : Calendar & 0.660 \\
\hline & & $\mathrm{C}_{52}$ : Searching Engine & 0.810 \\
\hline
\end{tabular}




\begin{tabular}{cclc}
\hline & & $\mathrm{C}_{61}$ : Test / exam tools & 0.883 \\
Measuring Tools & 0.883 & $\mathrm{C}_{62}$ : Question bank management & 0.883 \\
& & $\mathrm{C}_{63}$ : Automated test management & 0.923 \\
\hline \multirow{2}{*}{ Evaluation Tools } & \multirow{2}{*}{0.903} & $\mathrm{C}_{71}$ : Student Tracking & 0.903 \\
& & $\mathrm{C}_{72}$ : Courses / training management & 0.923 \\
\hline \multirow{2}{*}{ Security } & $\mathrm{C}_{81}$ : Authentication & 0.460 \\
& \multirow{2}{*}{0.227} & $\mathrm{C}_{82}$ : The frequency of publication of Security Patch & 0.460
\end{tabular}

As seen at Table 14, Content Management and Development is the most important criteria with the 28.7\% value. It is seen that Evaluation Tools and Communication, Interaction and Cooperation has almost equal importance with $19.8 \%$ and $19.4 \%$ value. Measuring Tools (16.0\%), Ease of Use (7.4\%), Productivity Tools (4.1\%), Security (3.1\%) and Support (1.6\%) followed them.

Course templates are the most important ones between sub criteria of Content Management and Development. It is seen that Discussion / Forum is the most important criteria between sub criteria of Communication, Interaction and Cooperation. Courses / Training Management and Student Tracking have almost equal importance. Automated test management is more important than the other sub criteria of Measuring Tools. It is observed that Ease of Use and Security has almost equal importance. Searching Engine and Online Help is respectively the most important criteria between sub criteria of Productivity Tools and Support.

As seen at Table 15, the ranking is like that; Content Management and Development (96.3\%) has seen as the first criteria. With the equal importance of Evaluation Tools (90.3\%) and Communication, Interaction and Cooperation (90.3\%) is second order. Measuring Tools (88.3\%), Productivity Tools (70.0\%), Ease of Use (46.6\%), Support (34.0\%), and Security (22.7\%) follows them respectively. The criteria ranking, obtained from Fuzzy AHP and Fuzzy TOPSIS shows a little difference from each other.

Table 16. Alternative importance weights and rankings

\begin{tabular}{lcccccc}
\hline Alternative & \multicolumn{2}{c}{ Fuzzy AHP } & \multicolumn{2}{c}{ Fuzzy TOPSIS } & \multicolumn{2}{c}{ Integrated Method } \\
\cline { 2 - 7 } & Weight & Ranking & Closeness Index & Ranking & Closeness Index & Ranking \\
\hline Atutor & 0.233 & 3 & 0.611 & 2 & 0.317 & 2 \\
Claroline & 0.237 & 2 & 0.597 & 3 & 0.310 & 3 \\
Sakai & 0.004 & 6 & 0.101 & 6 & 0.043 & 6 \\
Moodle & 0.363 & 1 & 0.674 & 1 & 0.355 & 1 \\
Olat & 0.009 & 5 & 0.169 & 5 & 0.078 & 5 \\
Dokeos & 0.154 & 4 & 0.306 & 4 & 0.132 & 4 \\
\hline
\end{tabular}

As seen at Table 16, Moodle is the best alternative with the degree of $36.3 \%$. The second and third LMS are Claroline and Atutor with the degree of $23.3 \%$ and $23.7 \%$. The fourth is Dokeos (15.4\%) and the last 
two LMS are Olat $(0.09 \%)$ and Sakai $(0.04 \%)$ and it is seen that these two alternatives remained quite inadequate in terms of meeting the criteria. Analyzing the results of Fuzzy TOPSIS and integrated methods, it is seen only the ranking of Moodle and Atutor changed, others have the same ranking. Only the closeness indexes differ from each other because of the linguistics variable, used in Fuzzy AHP, it is smaller than used TOPSIS.

The results are adaptable with literature. As we talk about Sec. 2 the Moodle emerges the most preferred system between alternatives. The criteria especially the main criteria are almost the same as discussed in the literature. Differ from the others, we found the importance weight of these criteria.

\section{CONCLUSION}

With the development of technology, distance education has become an important role in teaching and learning and it is actively used almost in every developed or developing countries. Therefore, requirement for systems served e-learning increase day by day. These systems called LMS and every system has different features. In this study, we want to guide universities and educational organizations for selection LMS and show criteria importance weights for LMS evaluation.

We used fuzzy MCDM techniques to define important criteria and to select the best alternative. AHP and TOPSIS reflect the opinion of experts. But, traditional techniques do not clearly express human thoughts. Decision makers are unwilling to make certain judgments so; they prefer discrete values rather than exact values to reflect the human thoughts. Because of this, the fuzzy AHP and fuzzy TOPSIS are used in this study. An integrated method for obtaining more certain results are made too. The criteria weights obtained by Fuzzy AHP are used during alternative ranking by Fuzzy TOPSIS in integrated method.

After evaluating criteria with three methods, Content Management and Development has emerged as the most important criteria. In the same way Moodle, emerged as the best alternative, can be selected in all methods. And also it can be seen that Moodle is easily preferred by many institutions in Turkey. So it can be said that these results seem to be logical and consistent.

According to these results the superiority of these methods to each other or weak point that is relative to one another cannot be criticized. This study showed these three methods can be easily used in the selection of LMS process.

For future studies, the well-known MCDM techniques such as ANP (Analytic Network Process), VIKOR (VlseKriterijumska Optimizacija I Kompromisno Resenje), PROMETHEE (Preference Ranking Organization METHod for Enrichment Evaluation) and etc. can be used for evaluation and selection of LMS. Furthermore, the criteria used in this study are obtained by expert opinions and literature review. There are a quite number of criteria and these criteria can be defined as dependent and independent criteria. In this respect, DEMATEL (The Decision Making Trial and Evaluation Laboratory Method) method can be employed to determine important evaluation main criteria and sub-criteria. 


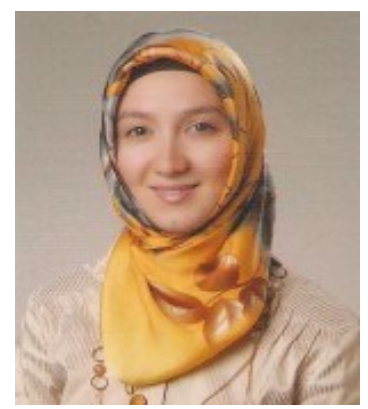

Yasemin ALTUN TURKER is a PhD student at Institute of Natural Sciences, Sakarya \& Karabuk University. She was graduated with a Bachelor of Science degree in Industrial Engineering from Gaziantep University. Then she received her master's degree in Industrial Engineering from Kocaeli University. Her fields of interest include multi criteria decision making methods, supply chain management, simulation and mathematical modelling.

\section{Yasemin ALTUN TURKER}

Department of Industrial Engineering, Institute of Natural Sciences

Adress: Karabuk University, 78050, Karabuk, Turkey

Phone: +90-370-4187240,

E-mail: ysmnaltun@yahoo.com

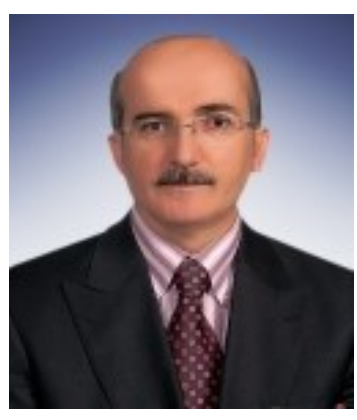

Dr. Kasim BAYNAL holds a Bachelor of Science degree in industrial engineering from Technical University of Istanbul, Turkey. He completed his master's degree at Yıldız University in Istanbul and gained his Ph.D. degree in Department of Management, Faculty of Economics and Management at Istanbul University. Dr. Kasım BAYNAL is an Associated Professor in Department of Industrial Engineering at the Engineering Faculty of Kocaeli University. In 2018, he was appointed to Kyrgyz-Turk Manas University by Council of Higher Education (YÖK). He still continues his scientific studies at Kyrgyz-Turk Manas University. His main study areas of research interest are design of experiments, Taguchi method, total quality management and statistical analysis methods. He has over than 20 journal articles published in international indexes journals and other national and international articles, papers submitted to international meetings. He is a member of the Chamber of Mechanical Engineers of Turkey and the Association of Operations Research.

\section{Dr. Kasim BAYNAL}

Kocaeli University Faculty of Engineering Department of Industrial Engineering,

Adress: Umuttepe Campus İzmit, Kocaeli, TURKEY 41380 Phone: +902623033324,

E-mail: kbaynal@kocaeli.edu.tr

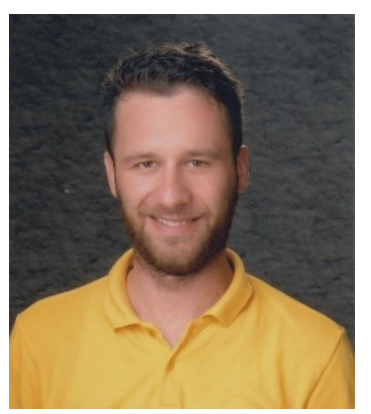

Turgay TURKER is a PhD student at Institute of Natural Sciences, Sakarya University. He was graduated with a Bachelor of Science degree in Industrial Engineering from Kocaeli University. Then he received his master's degree in Mechanical Engineering from Karabuk University. His fields of interest include multi criteria decision making methods, optimization, scheduling and constraint programming.

\section{Turgay TURKER}

Department of Industrial Engineering, Institute of Natural Sciences

Adress: Sakarya University, 54187, Sakarya, Turkey

Phone: +90-264-2955552,

E-mail: turgayturker55@gmail.com 


\section{REFERENCES}

Alshomrani, S. (2012). Evaluation of technical factors in distance learning with respect to open-source LMS. Asian Transactions on Computers, 2, 11-17.

Aydin, C. C., \& Birogul, S. (2008). E-Ogrenmede acik kaynak kodlu ogretim yonetim sistemleri ve Moodle [Open source learning management systems in e-learning and Moodle]. Bilisim Teknolojileri Dergisi, 1, 31-36.

Bakhoum, E. S. \& Brown, D. C. (2013). A hybrid approach using AHP-TOPSIS-entropy methods for sustainable ranking of structural materials. International Journal of Sustainable Engineering, 6(3), 212-224.

Browne, T., Jenkins, M., \& Walker, R. (2006). A longitudinal perspective regarding the use of VLEs by higher education institutions in the United Kingdom. Interactive Learning Environments, 14(2), 177-192.

Cavus, N. (2010). The evaluation of Learning Management Systems using an artificial intelligence fuzzy logic algorithm. Advances in Engineering Software, 41, 248-254.

Chang, D. Y. (1996). Applications of the extent analysis method on fuzzy AHP. European Journal of Operational Research, 95(3), 649-655.

Chao, R. J., \& Chen, Y. H. (2009). Evaluation of the criteria and effectiveness of distance e-learning with consistent fuzzy preference relations. Expert Systems with Applications, 36, 10657-10662.

Chen, S., \& Li, Y. (2009). A research of fuzzy AHP approach in evaluating distance education system alternatives. In Proceedings of the 1st International Workshop on Education Technology and Computer Science, 741-745.

Chen, C. T. (2000). Extensions of the TOPSIS for Group Decision-Making under Fuzzy Environment. Fuzzy Sets and Systems, 114, 1-9.

Chen, L. H., \& Hung, C. C. (2010). An integrated fuzzy approach for the selection of outsourcing manufacturing partners in pharmaceutical R\&D. International Journal of Production Research, 48(24), 7483-7506.

Colace F., \& De Santo, M. (2008). Evaluation models for e-learning platforms and the AHP approach: A case study. [Accessed 02 November 2015]. Available at: <http://tir.ipsitransactions.org/2011/January/Paper\%2004.pdf>.

Demirel, T., Musdal, H., Demirel, N. C., \& Yucenur, G. N. (2009). Multi-criteria evaluation of land cover policies using fuzzy AHP and fuzzy ANP: The case of Turkey. Human and Ecological Risk Assessment, 15(4), 746-764.

Chan, F. T. S., \& Kumar, N. (2007). Global supplier development considering risk factors using fuzzy extended AHP-based approach. Omega, 35(4), 417-431.

Goh, H. H., Kok, B. C., Yeo, H. T., Lee, S. W., \& Zin, A. A. M. (2013). Combination of TOPSIS and AHP in load shedding scheme for large pulp mill electrical system. International Journal of Electrical Power \& Energy Systems, 47, 198-204.

Hassanzadeh, A., Kanaani, F., \& Elahi, S. (2012). A model for measuring e-learning systems success in universities. Expert Systems with Applications, 39, 10959-10966.

Hwang, C. L., \& Yoon, K. (1981). Multiple attribute decision making: methods and applications: a stateof-the-art survey. New York: Springer-Verlag. 
Itmazi, J., Gea, M. M., Paderewski, P., \& Gutierrez, F. L. (2005). A Comparison and Evaluation of Open-Source Learning Management Systems. In Proceedings of the IADIS International Conference Applied Computing, 80-86.

Kahraman, C., Cebeci, U., \& Ruan, D. (2004). Multi-attribute comparison of catering service companies using fuzzy AHP: The case of Turkey. International Journal of Production Economics, 87, 171184.

Kanuka, H., \& Anderson, T. (2007). Ethical issues in qualitative e-learning research. International Journal of Qualitative Methods, 6(2), 20-39.

Kaya, M. (2012). Distance education systems used in universities of Turkey and Northern Cyprus, Procedia-Social and Behavioral Sciences, 31, 676-680.

Lonn, S., \& Teasley, S. D. (2009). Saving time or innovating practice: investigating perceptions and uses of Learning Management Systems. Computers \& Education, 53, 686-694.

Majumdar, A., Sarkar, B., \& Majumdar, P. K. (2005), Determination of quality value of cotton fibre using hybrid AHP-TOPSIS method of multi-criteria decision-making. The Journal of the Textile Institute, 96(5), 303-309.

Mahmoodzadeh, S., Shahrabi, J., Pariazar, M., \& Zaeri, M. S., (2007). Project selection by using fuzzy AHP and TOPSIS technique. International Journal of Social, Human Science and Engineering, $1(6), 302-307$.

Moore, M. G., \& Kearsley, G. (2005). Distance education: a systems view, (2nd ed.). Canada: Wadsworth Publishing.

Olcott, D. (2003). Accreditation in the digital era: preparing for the new distance education landscape. In S. Panda (Ed.), Planning and management in distance education (pp. 253-261). London: Kogan Page Limited.

Ozan, O. (2008). Ogrenme yonetim sistemlerinin degerlendirilmesi [Evaluation of learning management systems]. XIII. Turkiye'de Internet Konferansi Bildirileri, [Accessed 12 September 2015]. Available at: <http://inet-tr.org.tr/inetconf13/kitap/ozan_inet08.pdf>.

Razmi, J., Songhori, M. J., Khakbaz, M. H. (2009). An integrated fuzzy group decision making/fuzzy linear programming (FGDMLP) framework for supplier evaluation and order allocation. International Journal of Advanced Manufacturing Technology, 43, 590-607.

Reis, Z. A., Baktir, H. O., Celik, B., Erkoc, M. F., Ozcakir, F. C., Ozdemir, S., \& Sahin, K. (2012). Acik kaynak kodlu ogrenme yonetim sistemleri uzerine bir karsilastirma calismasi [A comparison study on open source learning management systems]. Egitim ve Ogretim Arastirmalari Dergisi, $1,42-58$.

Saaty, T. L. (1977). A scaling method for priorities in hierarchical structures. Journal of Mathematical Psychology, 15(3), 234-281.

Saaty, T. L. (1980). The Analytic Hierarchy Process. New York: McGraw-Hill.

Shee, D. Y., \& Wang Y. S. (2008). Multi-criteria evaluation of the web based e-learning system: A methodology based on learner satisfaction and its applications. Computers \& Education, 50, 894-905.

Shyjith, K., Ilangkumaran, M., \& Kumanan, S. (2008). Multi-criteria decision-making approach to evaluate optimum maintenance strategy in textile industry. Journal of Quality in Maintenance Engineering, 14(4), 375-386. 
Stella, A., \& Gnanam, A. (2004). Quality assurance in distance education: the challenges to be addressed. Higher Education, 47, 143-160.

Sun, P. C., Tsai, R. J., Finger, G., Chen, Y. Y., \& Yeh, D. (2008). What drives a successful e-learning? An empirical investigation of the critical factors influencing learner satisfaction. Computers \& Education, 50, 1183-1202.

Tsaur, S. H., Chang, T. Y., \& Yen, C. H. (2002). The Evaluation of Airline Service Quality by Fuzzy MCDM. Tourism Management, 23, 107-115.

Van Laarhoven, P. J. M., \& Pedrycz, W. (1983). A fuzzy extension of Saaty's priority theory. Fuzzy Sets and System, 11(3), 199-227.

Wang, W. T., \& Wang, C. C. (2009). An empirical study of instructor adoption of web-based learning systems. Computers \& Education, 53, 761-774.

Yu, X., Guo, S., Guo, J., \& Huang, X. (2011). Rank B2C e-commerce websites in e-alliance based on AHP and fuzzy TOPSIS. Expert Systems with Applications, 38, 3550-3557.

Zadeh, L. A. (1965). Fuzzy Sets. Information and Control, 8, 338-353.

Zheng, G., Zhu, N., Tian, Z., Chen, Y., \& Sun, B. (2012). Application of a trapezoidal fuzzy AHP method for work safety evaluation and early warning rating of hot and humid environments. Safety Science, 50, 228-239.

\section{APPENDIX}

Table 1. Main criteria evaluation form for Fuzzy AHP

\begin{tabular}{|l|l|l|l|l|l|l|l|l|l|}
\hline \multicolumn{2}{|c|}{ Main Criteria } & $\mathrm{C}_{1}$ & $\mathrm{C}_{2}$ & $\mathrm{C}_{3}$ & $\mathrm{C}_{4}$ & $\mathrm{C}_{5}$ & $\mathrm{C}_{6}$ & $\mathrm{C}_{7}$ & $\mathrm{C}_{8}$ \\
\hline $\mathrm{C}_{1}$ & Ease of Use & & & & & & & & \\
\hline $\mathrm{C}_{2}$ & Communication, Interaction and Cooperation & & & & & & & & \\
\hline$C_{3}$ & Content Management and Development & & & & & & & & \\
\hline$C_{4}$ & Support & & & & & & & & \\
\hline$C_{5}$ & Productivity Tools & & & & & & & & \\
\hline$C_{6}$ & Measuring Tools & & & & & & & & \\
\hline$C_{7}$ & Evaluation Tools & & & & & & & & \\
\hline$C_{8}$ & Security & & & & & & \\
\hline
\end{tabular}

Table 2. Sub-criteria evaluation form for Fuzzy AHP

\begin{tabular}{|l|l|l|l|l|l|l|l|l|l|l|l|l|l|l|l|l|l|l|l|l|l|l|}
\hline \multicolumn{2}{|c|}{ Sub-criteria } & $\mathrm{C}_{11}$ & $\mathrm{C}_{12}$ & $\mathrm{C}_{21}$ & $\mathrm{C}_{22}$ & $\mathrm{C}_{23}$ & $\mathrm{C}_{24}$ & $\mathrm{C}_{31}$ & $\mathrm{C}_{32}$ & $\mathrm{C}_{33}$ & $\mathrm{C}_{41}$ & $\mathrm{C}_{42}$ & $\mathrm{C}_{51}$ & $\mathrm{C}_{52}$ & $\mathrm{C}_{53}$ & $\mathrm{C}_{61}$ & $\mathrm{C}_{62}$ & $\mathrm{C}_{63}$ & $\mathrm{C}_{71}$ & $\mathrm{C}_{72}$ & $\mathrm{C}_{81}$ & $\mathrm{C}_{82}$ \\
\hline $\mathrm{C}_{11}$ & $\begin{array}{l}\text { Friendly } \\
\text { interface }\end{array}$ & & & & & & & & & & & & & & & & & & & & & \\
\hline $\begin{array}{l}\mathrm{C}_{12} \\
\text { Fystems } \\
\text { syible }\end{array}$ & & & & & & & & & & & & & & & & & & & & & \\
\hline
\end{tabular}




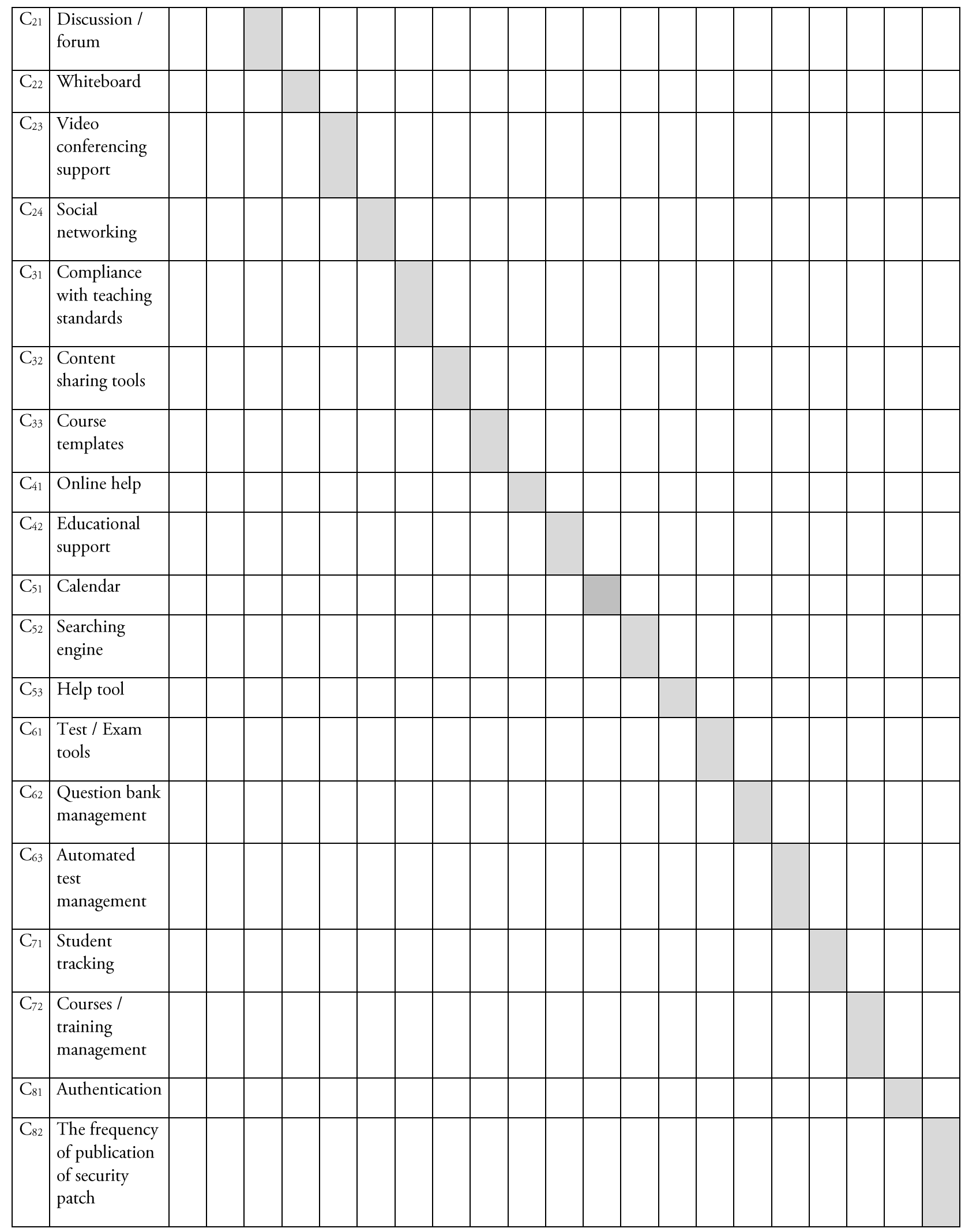


Table 3. Main criteria evaluation form for Fuzzy TOPSIS

\begin{tabular}{|c|c|c|c|c|c|c|c|c|}
\hline & Main Criteria & $\begin{array}{l}\text { Very } \\
\text { High }\end{array}$ & High & $\begin{array}{c}\text { Medium } \\
\text { High }\end{array}$ & Medium & $\begin{array}{l}\text { Medium } \\
\text { Low }\end{array}$ & Low & Very Low \\
\hline $\mathrm{C}_{1}$ & Ease of Use & & & & & & & \\
\hline $\mathrm{C}_{2}$ & $\begin{array}{l}\text { Communication, } \\
\text { Interaction and } \\
\text { Cooperation }\end{array}$ & & & & & & & \\
\hline $\mathrm{C}_{3}$ & $\begin{array}{l}\text { Content } \\
\text { Management and } \\
\text { Development }\end{array}$ & & & & & & & \\
\hline $\mathrm{C}_{4}$ & Support & & & & & & & \\
\hline $\mathrm{C}_{5}$ & Productivity Tools & & & & & & & \\
\hline $\mathrm{C}_{6}$ & Measuring Tools & & & & & & & \\
\hline $\mathrm{C}_{7}$ & Evaluation Tools & & & & & & & \\
\hline $\mathrm{C}_{8}$ & Security & & & & & & & \\
\hline
\end{tabular}

Table 4. Sub-criteria evaluation form for Fuzzy TOPSIS

\begin{tabular}{|c|c|c|c|c|c|c|c|c|}
\hline & & Very High & High & $\begin{array}{l}\text { Medium } \\
\text { High }\end{array}$ & Medium & $\begin{array}{l}\text { Medium } \\
\text { Low }\end{array}$ & Low & Very Low \\
\hline $\mathrm{C}_{11}$ & Friendly interface & & & & & & & \\
\hline $\mathrm{C}_{12}$ & Flexible systems & & & & & & & \\
\hline $\mathrm{C}_{21}$ & Discussion / forum & & & & & & & \\
\hline $\mathrm{C}_{22}$ & Whiteboard & & & & & & & \\
\hline $\mathrm{C}_{23}$ & $\begin{array}{l}\text { Video conferencing } \\
\text { support }\end{array}$ & & & & & & & \\
\hline $\mathrm{C}_{24}$ & Social networking & & & & & & & \\
\hline $\mathrm{C}_{31}$ & $\begin{array}{l}\text { Compliance with } \\
\text { teaching standards }\end{array}$ & & & & & & & \\
\hline $\mathrm{C}_{32}$ & Content sharing tools & & & & & & & \\
\hline $\mathrm{C}_{33}$ & Course templates & & & & & & & \\
\hline $\mathrm{C}_{41}$ & Online help & & & & & & & \\
\hline $\mathrm{C}_{42}$ & Educational support & & & & & & & \\
\hline $\mathrm{C}_{51}$ & Calendar & & & & & & & \\
\hline $\mathrm{C}_{52}$ & Searching engine & & & & & & & \\
\hline $\mathrm{C}_{53}$ & Help tool & & & & & & & \\
\hline $\mathrm{C}_{61}$ & Test / Exam tools & & & & & & & \\
\hline $\mathrm{C}_{62}$ & $\begin{array}{l}\text { Question bank } \\
\text { management }\end{array}$ & & & & & & & \\
\hline
\end{tabular}




\begin{tabular}{|c|l|l|l|l|l|l|l|l|}
\hline $\mathrm{C}_{63}$ & $\begin{array}{l}\text { Automated test } \\
\text { management }\end{array}$ & & & & & & & \\
\hline $\mathrm{C}_{71}$ & Student tracking & & & & & & & \\
\hline $\mathrm{C}_{72}$ & $\begin{array}{l}\text { Courses / training } \\
\text { management }\end{array}$ & & & & & & & \\
\hline $\mathrm{C}_{81}$ & Authentication & & & & & & & \\
\hline $\mathrm{C}_{82}$ & $\begin{array}{l}\text { The frequency of } \\
\text { publication of security } \\
\text { patch }\end{array}$ & & & & & & & \\
\hline
\end{tabular}

Table 5. Normalized fuzzy decision matrix for FAHP

$\begin{array}{lllllll}\mathrm{C}_{11} & \mathrm{C}_{12} & \mathrm{C}_{21} & \mathrm{C}_{22} & \mathrm{C}_{23} & \mathrm{C}_{24} & \mathrm{C}_{31}\end{array}$

\begin{tabular}{lll|lll|lll|l|l|l|l|l|l|l|l|l|l|l|l|l}
\hline A1 & 0.580 & 0.780 & 0.940 & 0.620 & 0.820 & 0.960 & 0.660 & 0.860 & 0.980 & 0.660 & 0.860 & 0.980 & 0.620 & 0.820 & 0.960 & 0.620 & 0.820 & 0.960 & 0.660 & 0.860 & 0.980
\end{tabular}

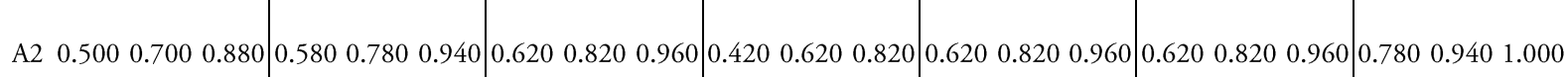

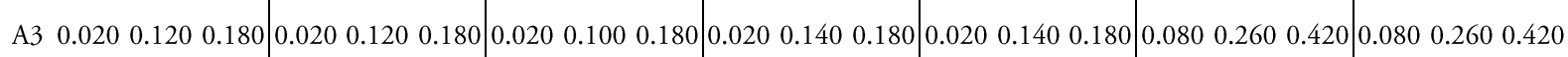

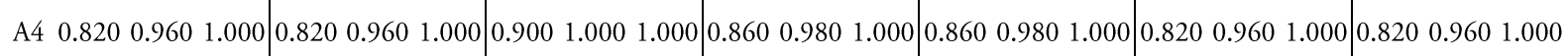

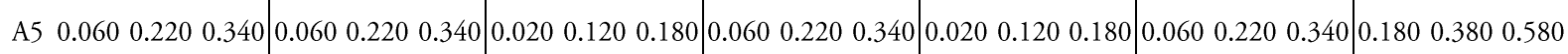

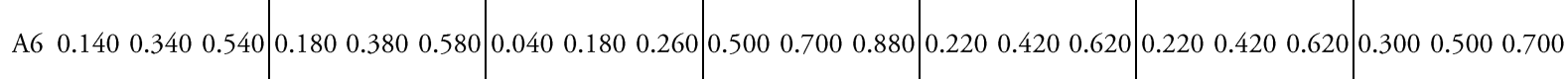

\begin{tabular}{llllllll}
\hline $\mathrm{C}_{32}$ & $\mathrm{C}_{33}$ & $\mathrm{C}_{41}$ & $\mathrm{C}_{42}$ & $\mathrm{C}_{51}$ & $\mathrm{C}_{52}$ & $\mathrm{C}_{53}$ \\
\hline
\end{tabular}

\begin{tabular}{llll|lll|llll|l|l|l|l|l|l|l|l|l|l|l|l}
\hline A1 & 0.520 & 0.680 & 0.780 & 0.620 & 0.820 & 0.960 & 0.620 & 0.820 & 0.940 & 0.660 & 0.840 & 0.940 & 0.660 & 0.840 & 0.940 & 0.780 & 0.940 & 1.000 & 0.660 & 0.860 & 0.980
\end{tabular}

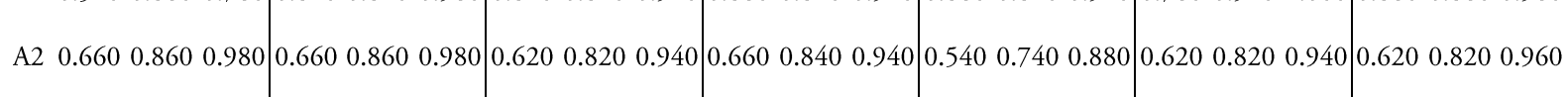

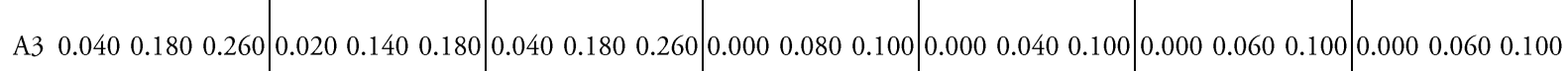
\begin{tabular}{lllllll|llll|llll|llll|l|l|l|l|l} 
A4 & 0.860 & 0.980 & 1.000 & 0.780 & 0.940 & 1.000 & 0.820 & 0.960 & 1.000 & 0.860 & 0.980 & 1.000 & 0.780 & 0.940 & 1.000 & 0.820 & 0.960 & 1.000 & 0.860 & 0.980 & 1.000
\end{tabular}

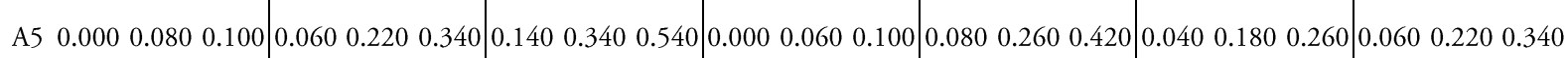
\begin{tabular}{llllllllllllll|llll|lll|l} 
A6 & 0.220 & 0.420 & 0.620 & 0.180 & 0.380 & 0.580 & 0.180 & 0.380 & 0.580 & 0.020 & 0.140 & 0.180 & 0.220 & 0.420 & 0.620 & 0.140 & 0.340 & 0.540 & 0.220 & 0.420 & 0.620 \\
\hline
\end{tabular}

$\begin{array}{lllllll}\mathrm{C}_{61} & \mathrm{C}_{62} & \mathrm{C}_{63} & \mathrm{C}_{71} & \mathrm{C}_{72} & \mathrm{C}_{81} & \mathrm{C}_{82}\end{array}$

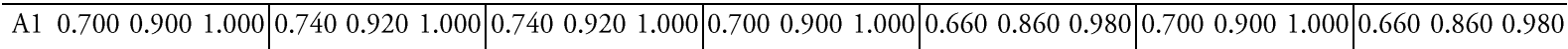

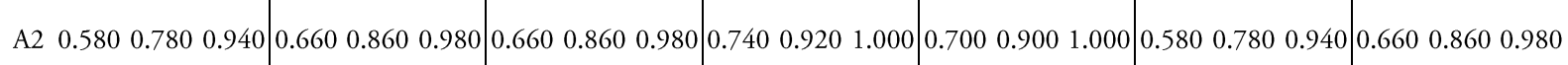

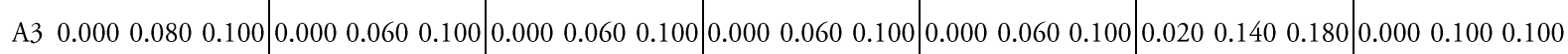

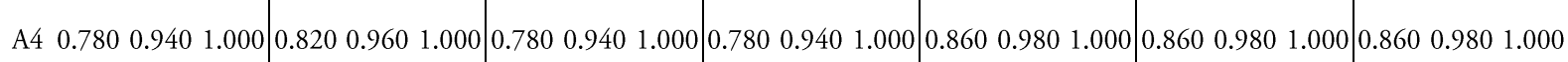

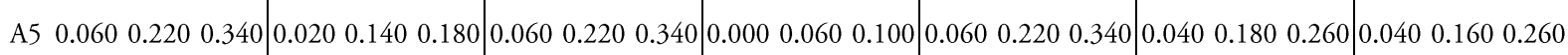

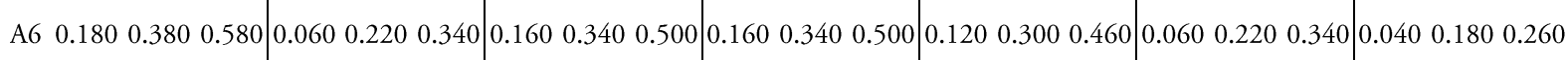


Table 6. Weighted normalized fuzzy decision matrix for TOPSIS

\begin{tabular}{|c|c|c|c|c|c|c|c|}
\hline & $\mathrm{C}_{11}$ & $\mathrm{C}_{12}$ & $C_{21}$ & $C_{22}$ & $\mathrm{C}_{23}$ & $\mathrm{C}_{24}$ & $C_{31}$ \\
\hline A1 & 0.1510 .3590 .620 & 0.2600 .5080 .787 & $\begin{array}{llll}0.515 & 0.808 & 0.980\end{array}$ & 0.4090 .7050 .941 & 0.4590 .7540 .960 & 0.4340 .7380 .960 & 0.4880 .7910 .980 \\
\hline A2 & 0.1300 .3220 .581 & 0.2440 .4840 .771 & 0.4840 .7710 .960 & $\begin{array}{llll}0.260 & 0.508 & 0.787\end{array}$ & 0.4590 .7540 .960 & 0.4340 .7380 .960 & 0.5770 .8651 .000 \\
\hline A3 & 0.0050 .0550 .119 & $\begin{array}{llll}0.008 & 0.074 & 0.148\end{array}$ & 0.0160 .0940 .180 & 0.0120 .1150 .173 & 0.0150 .1290 .180 & $0.056 \begin{array}{lll}0.234 & 0.420\end{array}$ & 0.0590 .2390 .420 \\
\hline A4 & 0.2130 .4420 .660 & 0.3440 .5950 .820 & 0.7020 .9401 .000 & 0.5330 .8040 .960 & 0.6360 .9021 .000 & 0.5740 .8641 .000 & 0.6070 .8831 .000 \\
\hline A5 & 0.0160 .1010 .224 & 0.0250 .1360 .279 & 0.0160 .1130 .180 & 0.0370 .1800 .326 & 0.0150 .1100 .180 & $0.0420 .198 \quad 0.340$ & $\begin{array}{llll}0.133 & 0.350 & 0.580\end{array}$ \\
\hline A6 & 0.0360 .1560 .356 & $\begin{array}{lll}0.076 & 0.236 & 0.476\end{array}$ & 0.0310 .1690 .260 & 0.3100 .5740 .845 & 0.1630 .3860 .620 & 0.1540 .3780 .620 & 0.2220 .4600 .700 \\
\hline & & & & $\mathrm{C}_{42}$ & $\mathrm{C}_{51}$ & $\mathrm{C}_{52}$ & $C_{5}$ \\
\hline
\end{tabular}

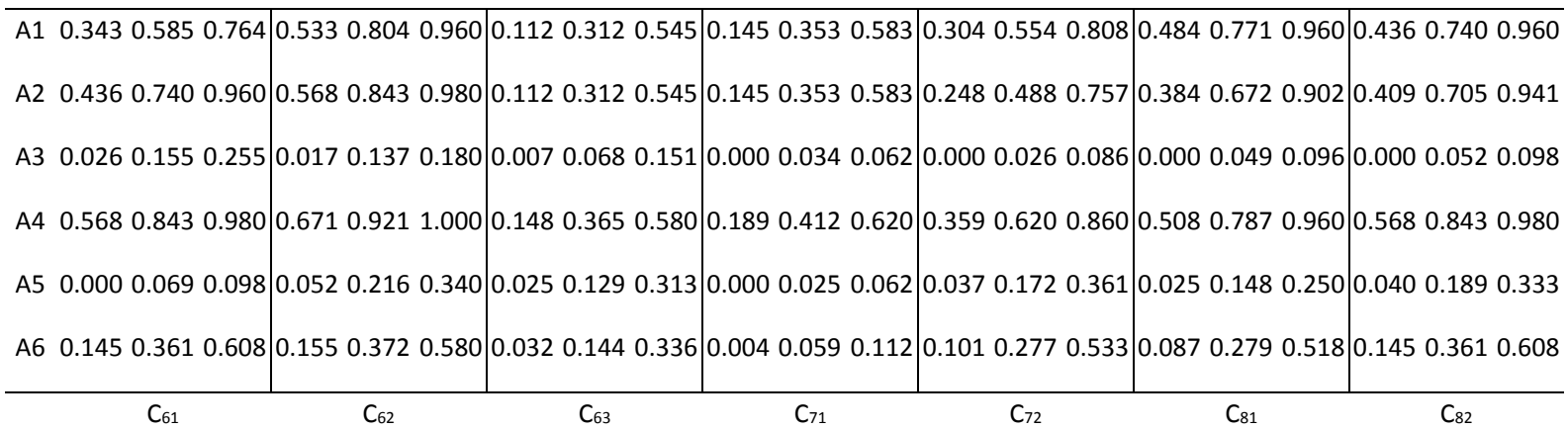

\begin{tabular}{lllllll|llll|llll|lll|lll|l}
\hline A1 & 0.490 & 0.810 & 1.000 & 0.518 & 0.828 & 1.000 & 0.577 & 0.865 & 1.000 & 0.518 & 0.828 & 1.000 & 0.515 & 0.808 & 0.980 & 0.182 & 0.414 & 0.660 & 0.172 & 0.396 & 0.647 \\
A2 & 0.406 & 0.702 & 0.940 & 0.462 & 0.774 & 0.980 & 0.515 & 0.808 & 0.980 & 0.548 & 0.846 & 1.000 & 0.546 & 0.846 & 1.000 & 0.151 & 0.359 & 0.620 & 0.172 & 0.396 & 0.647 \\
A3 & 0.000 & 0.072 & 0.100 & 0.000 & 0.054 & 0.100 & 0.000 & 0.056 & 0.100 & 0.000 & 0.05 & 0.100 & 0.000 & 0.056 & 0.100 & 0.005 & 0.064 & 0.119 & 0.000 & 0.046 & 0.066 \\
A4 & 0.546 & 0.846 & 1.000 & 0.574 & 0.864 & 1.000 & 0.608 & 0.884 & 1.000 & 0.577 & 0.865 & 1.000 & 0.671 & 0.921 & 1.000 & 0.224 & 0.451 & 0.660 & 0.224 & 0.451 & 0.660 \\
A5 & 0.042 & 0.198 & 0.340 & 0.014 & 0.126 & 0.180 & 0.047 & 0.207 & 0.340 & 0.000 & 0.055 & 0.100 & 0.047 & 0.207 & 0.340 & 0.010 & 0.083 & 0.172 & 0.010 & 0.074 & 0.172 \\
A6 & 0.126 & 0.342 & 0.580 & 0.042 & 0.198 & 0.340 & 0.125 & 0.320 & 0.500 & 0.118 & 0.313 & 0.500 & 0.094 & 0.282 & 0.460 & 0.016 & 0.101 & 0.224 & 0.010 & 0.083 & 0.172 \\
\hline
\end{tabular}


Table 7. Weighted normalized fuzzy decision matrix for integrated method

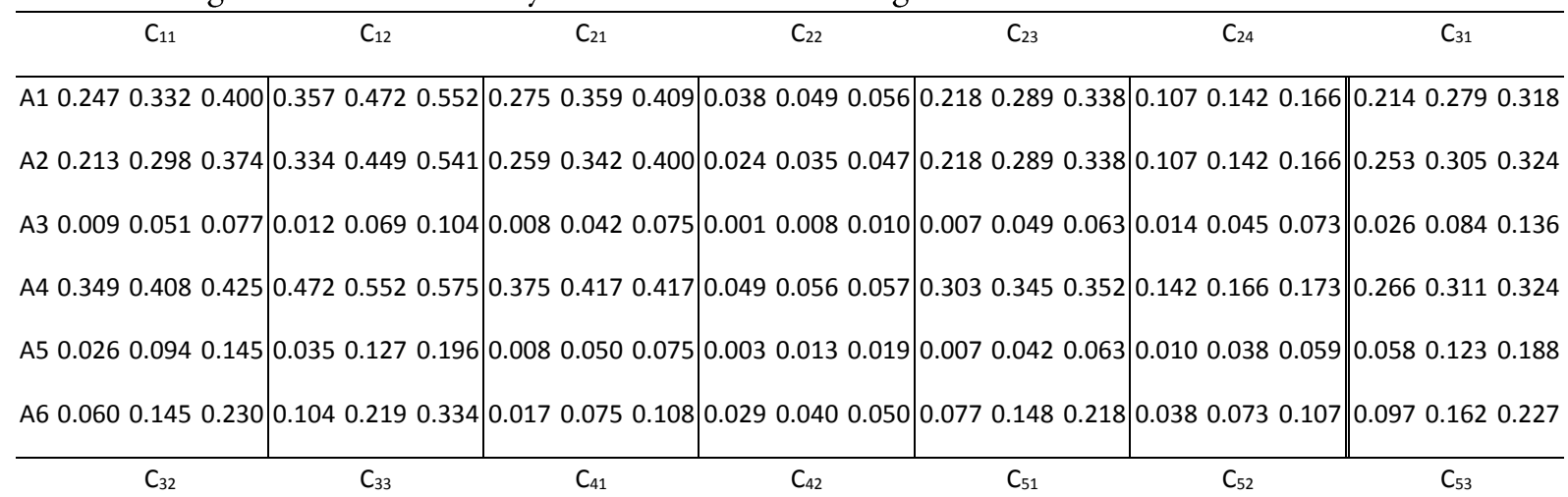

\begin{tabular}{|c|c|c|c|c|c|c|}
\hline $\begin{array}{llll}A 1 & 0.132 & 0.172 & 0.197\end{array}$ & 0.2620 .3470 .406 & $\begin{array}{llll}0.347 & 0.458 & 0.525\end{array}$ & 0.2910 .3700 .415 & $\begin{array}{llll}0.145 & 0.185 & 0.207\end{array}$ & $\begin{array}{llll}0.313 & 0.377 & 0.401\end{array}$ & $\begin{array}{llll}0.250 & 0.326 & 0.371\end{array}$ \\
\hline A2 $0.167 \quad 0.2180 .248$ & 30.2790 .3640 .415 & $\left|\begin{array}{lll}0.347 & 0.458 & 0.525\end{array}\right|$ & $\begin{array}{lll}0.291 & 0.370 & 0.415\end{array}$ & 0.1190 .1630 .194 & $\begin{array}{lll}0.249 & 0.329 & 0.377\end{array}$ & $\begin{array}{llll}0.235 & 0.311 & 0.364\end{array}$ \\
\hline A3 0.0100 .0460 .066 & 50.0080 .0590 .076 & $\begin{array}{lll}0.022 & 0.101 & 0.145\end{array}$ & 0.0000 .0350 .044 & 0.0000 .0090 .022 & $\begin{array}{lll}0.000 & 0.024 & 0.040\end{array}$ & $\begin{array}{lll}0.000 & 0.023 & 0.038\end{array}$ \\
\hline $\begin{array}{lllll} & 0.218 & 0.248 & 0.253\end{array}$ & $\begin{array}{llll}0.330 & 0.398 & 0.423\end{array}$ & $\begin{array}{lll}0.458 & 0.537 & 0.559\end{array} \mid$ & $\begin{array}{lll}0.379 & 0.432 & 0.441\end{array}$ & 0.1720 .2070 .220 & $\begin{array}{lll}0.329 & 0.385 & 0.401\end{array} \mid$ & $\begin{array}{lll}0.326 & 0.371 & 0.379\end{array}$ \\
\hline A5 0.0000 .0200 .025 & 5.0250 .0930 .144 & $\begin{array}{lll}0.078 & 0.190 & 0.302\end{array}$ & $\begin{array}{lll}0.000 & 0.026 & 0.044\end{array}$ & $\begin{array}{lll}0.018 & 0.057 & 0.092\end{array}$ & $\begin{array}{lll}0.016 & 0.072 & 0.104\end{array}$ & 0.0230 .0830 .129 \\
\hline A6 $0.0560 .106 \quad 0.157$ & $\begin{array}{llll}0.076 & 0.161 & 0.245\end{array}$ & $\begin{array}{lll}0.101 & 0.212 & 0.324\end{array}$ & 0.0090 .0620 .079 & $\begin{array}{lll}0.048 & 0.092 & 0.136\end{array}$ & $\begin{array}{lll}0.056 & 0.136 & 0.217\end{array}$ & $\begin{array}{llll}0.083 & 0.159 & 0.235\end{array}$ \\
\hline
\end{tabular}

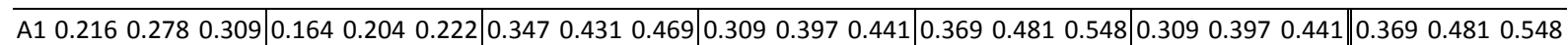

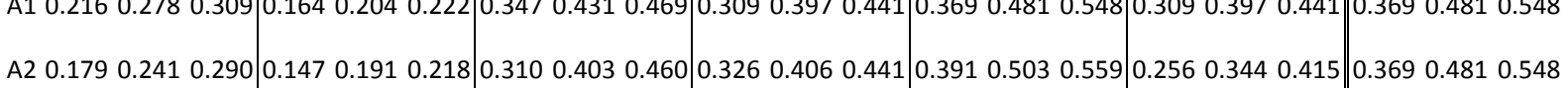

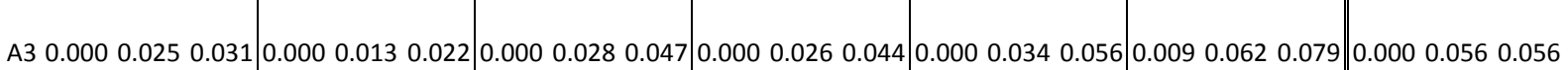

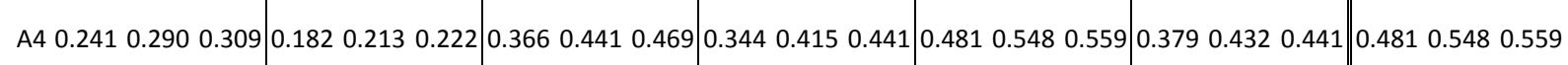

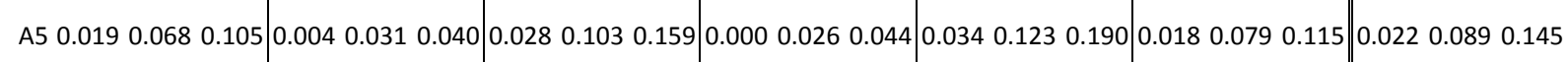

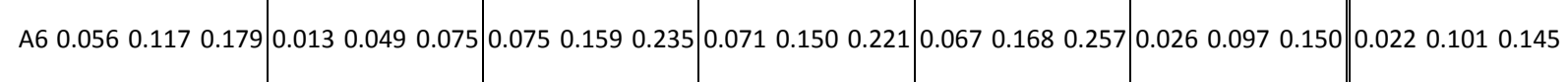

